\title{
Miranda
}

Revue pluridisciplinaire du monde anglophone /

Multidisciplinary peer-reviewed journal on the English-

speaking world

$14 \mid 2017$

Early American Surrealisms, 1920-1940 / Parable Art

\section{Frozen Passers-By}

Proustian Ghosts and Body Norms in The Sartorialist Fashion Blog

\section{Laurent Jullier}

\section{OpenEdition}

\section{Journals}

Electronic version

URL: http://journals.openedition.org/miranda/10062

DOI: 10.4000/miranda.10062

ISSN: 2108-6559

\section{Publisher}

Université Toulouse - Jean Jaurès

\section{Electronic reference}

Laurent Jullier, "Frozen Passers-By", Miranda [Online], 14 | 2017, Online since 18 April 2017, connection on 16 February 2021. URL: http://journals.openedition.org/miranda/10062 ; DOI: https://doi.org/ 10.4000/miranda. 10062

This text was automatically generated on 16 February 2021

\section{(c) $(1) \&$}

Miranda is licensed under a Creative Commons Attribution-NonCommercial-NoDerivatives 4.0 International License. 


\title{
Frozen Passers-By
}

\author{
Proustian Ghosts and Body Norms in The Sartorialist Fashion Blog
}

\author{
Laurent Jullier
}

Scott Schuman is a professional photographer whose work features in magazines like $G Q$, Vogue or Interview, and in ad campaigns of brands such as The Gap, Nespresso, Kiehl's or Burberry. In 2005 he founded a fashion blog called The Sartorialist ${ }^{1}$, which quickly gained in popularity on the net and ended up getting a worldwide following. Two years later, it was picked by <time.com> as one of the 25 best blogs in the world ${ }^{2}$ and by Time Magazine as one of the 100 top design influencers ${ }^{3}$. The exact amount of connections to The Sartorialist is not public, but it could be around half a million page views a day ${ }^{4}$, allowing Mr. Shuman to "theoretically earn over $\$ 100,000$ per month on advertising alone"s. At the same time, countless news articles and blog posts have taken it as a topic and parodies flourished on the web $^{6}$, not to forget deadly serious "SLABTheory guaranteed" academic dissertations dedicated to the craze ${ }^{7}$. Last but not least, several books were published by Penguin, displaying anthologies of the pictures available on the site.

Since the internet offers thousands of fashion blogs, the amazing success of The Sartorialist needs some explaining. Its two more valuable characteristics are probably diversity and talent. Regarding diversity, The Sartorialist is a never-ending photography portfolio. About one third of the posting is dedicated to the "sanctified" professional field of fashion (the "On the scene..." series), while two-thirds are dedicated to the "secular" one (the "On the street..." series). The former is embodied by models, fashion designers and editors, fashionistas and international jetsetters; the latter is verbally and visually made by the rest of us. Verbally because any registered user of the blog is free to comment on the photograph of his or her choice; and visually because the site is famous for displaying pictures of elegant anonymous passers-by. Indeed, when he plays the flâneur around his home in Manhattan or when his professional trips give him a short respite-that is why so many photos are taken in Paris and Milano, where the fashion shows take place-Mr. Schuman keeps proving he has got an "eye for the sharp-dressed Everyman"8. It is where talent comes in-on both sides of the camera lens. Anybody just standing at the corner can apparently be selected; anybody, in a 
sense, who's got it, since Mr. Schuman's aim is not to record the everchanging spectacle of the street, but to flush Beauty out of the downtown crowd: "I'm not reporting on people, he explained. What I am looking for is a certain grace." "

The motto is clear, but it raises some questions this essay intends to answer. How are Mr. Schuman's pictures composed? How are we supposed to react when watching them? Is fashion blogging a mere extension of fashion business? Or is The Sartorialist a postmodern way to solve aesthetic and existential problems about the ephemeral nature of the present moment and the sweet and sour taste of some instant epiphanies prompted by brief urban encounters? Unless, in a more mundane way, the "grace" it worships hides some ethical questions about gaze and norms.

\section{Inspiration and fictionalization}

Fashion blogs, as combinations of old and new media (the venerable art of photography matched with the newly born techniques of blogging), obviously seem to be tailor-made for Visual Culture Studies. Not only do they convey the usual mysteries of the photographic apparatus, but they make it possible to understand how the pictures they display are used, thanks to the users' comments. Today's photograph for instance, "Wednesday, December 11, 2013. On The Scene... Aesop, Bleecker St., New York"10, shows a pale young woman with sophisticated hair; she sells expensive Australian skincare products, and the atmosphere of the store she is standing in is warm and peaceful.

A simple contemplative gaze, for many users, is an appropriate way to react:

"I love her style... hair, clothes, accessories, minimal makeup - etc." (<wendy>)

"oh my god she is the coolest!! love everything about her vibe and the way she

styles herself:)" (<The Minx>)

More simply, close to the "likes" and "dislikes" of the social networks, one can read:

"like it" $(<\mathrm{Mc}>)$

"LOVELOVELOVELOVELOVE" (<galsandan>)

But some users display more cultural comments:

“WoW! Frida Kahlo meets Gibson Girl! She's Beautiful!!” (<Martha Miller>)

“Half-Victorian, half-90's grunge. Cool." (<LIZPR $>$ )

Thanks to photographic mimesis, there are no major differences between seeing this young woman in the real world and seeing her on a computer screen, as long as the observer does not wish to interact with the model. That is why the two richest uses of The Sartorialist-i.e., the uses leading to the most personal and original comments-are inspiration and fictionalization. Inspiration is the process by which we build the passerby as a model who displays fashionable items, unexpected combinations of clothes or gestures that we categorize as graspable signs, whether it be for our own use ("I could wear this too") or for a gift. One example is the "Gavroche-like" woman wearing a bomber and oversized tweed trousers of "Monday, November 4, 2013. On the Street... Fourteenth St., New York" ${ }^{11}$. Some users found a confirmation of their own taste in her outfit:

"Love the jacket, I have one just like it from H\&M :-)" (<CORY SCOTT>)

But real inspiration means an invitation to go shopping:

"The proportions are perfect and I'm going to hunt for a jacket like that now."

(<Anna-bird $>$ )

The problem is: The Sartorialist is not a commercial blog, and nobody will answer to: 
"I want that jacket, where can I get it?" (<Te>)

Regular visitors know it, and yearn after the impossible-to-find items. And here is where inspiration joins fictionalization:

"I want to know everything about her outfit. Sigh." (<sk>)

Fictionalization is the process by which we construct the passerby (either in real life or on the screen) as a character in a story waiting to be told. Let's go back to the pale shopgirl. Sometimes fictionalization is reduced to folk psychology:

"I like how she looks at you Scott, full of strength with a hint of curiosity..."

(<Anne>)

"Rebel inside! love her" (<alessandra de leonardis>)

Other times it is a simple way to tell one's own story, whether it be the past:

"Reminds me of my undergrad days..." (<une chatte grise>)

or the future:

"I want to be him when I grow up" (<milex>)12

But The Sartorialist sometimes provides the same kind of support to these rewritings of daily life as some of Cindy Sherman's series of photos of herself: both tend to be considered as film stills of a film that does not exist elsewhere than in the gaze of the observer:

“Her simple glance tells stories! :)" (<andreea>) $)^{13}$

See for instance "Wednesday, November 20, 2013. On the Street... Lafayette St., New York"14. This is the picture of another young and beautiful woman (some of the 80 comments compare her with a range of actresses going from Sophia Loren to Eva Mendes). Elicited fictions can be vague:

"I think I will dream this photo tonight!" (<Goran>)

Or more specific:

“I can imagine this beauty in a night dress.... Boys! Prepare the red carpet!" (<Maite

Jiménez>)

Sometimes they are related to the user himself:

"I don't care Scott - marry us!" (<jdit>)

"OMG, she is so beautiful! I would love to know her!" (<StreetLounge>)

It can even inspire wishful or magical thinking, as it is the case with the November 4 Gavroche girl:

"If Freaky Friday could really happen, I'd want to switch places with her."

$(<\text { shani }>)^{15}$

"Yes! I want to be that lady..." (<berenger>)

This kind of fictionalization has ancestors in the history of literature. More precisely, it refers to the writers who were bearing witness to the changes brought by "modern life". Consequently, before going further in the analysis of The Sartorialist, and in order to understand what is at stake here, a short return to the past will be useful.

\section{The gaze of the flâneur}

To freeze attractive passers-by isn't the prerogative of the photographic apparatus: in real life, it's even a commonplace optical act. Anybody wandering downtown in a big city and passing evanescent silhouettes of pedestrians in a hurry can do it. And s/he is likely to feel the same as Marcel, the narrator of In Search of Lost Time, when he 
glimpses girls from his moving carriage. From time to time, a silhouette moves us and "shoots the arrows of Beauty at our heart, and makes us wonder at times whether Beauty in this world is ever anything other than the makeweight that our imagination, overwrought by regret, adds to a fragmentary and fleeting passerby." ${ }^{16}$ Then as soon as the arrow is shot, the shooter vanishes, being taken by the flow of the crowd, as for Marcel: "Mme de Villeparisis's carriage went too quickly for me to do more than glimpse the girl coming up toward us"17.

The brevity of the encounter and its bitter taste of nevermore leave us with a feeling of incompletion. As for Marcel, he takes it hard: "the loss of every girl glimpsed, aggravated the state of agitation in which I spent my days." ${ }^{18}$ And the same goes for Gérard de Nerval in An Alley in the Luxembourg Gardens or Charles Baudelaire in To a Woman Passing By, two poems about this kind of brief-therefore-sad encounter. "A gleam. then night! O fleeting beauty, wrote Baudelaire. Your glance has given me sudden rebirth / Shall I see you again only in eternity? / Somewhere else, very far from here! Too late! Perhaps never!" 19 It is no surprise that Walter Benjamin, when he was working on the invention of flâneurs in the mid-19th Century, devoted an entire essay to Baudelaire: only a flâneur masters "the art of enjoying a crowd", which comes with "the love of masks and masquerade and the passion for roaming"20; only a flâneur moves so aimlessly and so slowly s/he can be harmed by the arrows of Beauty. Unlike a courtly or an Elizabethan lover, "the delight of the urban poet is love-not at first sight, but at last sight" ${ }^{21}$, wrote Benjamin, since her or his imagination only starts to work because of the vanishing.

But some doubt remains: is the arrow shot by the passer-by or by ourselves, i.e., was the passerby really the one or is the encounter so brief it only allows our imagination to fill in the missing elements of an unfinished portrait? Is Beauty a fact or a personal projection? In In Search of Lost Time, where analyzing one's daily experiences according to the imagination is one of the main topics, Marcel is attracted by the second explanation: "Had I thought her so lovely only because I had caught a mere glimpse of her? Perhaps." ${ }^{22}$ Even if Proust is by no means a Romantic, this second explanation is more Romantic; indeed, being aware of the projective nature of Beauty allows one to feel blue in a somehow satisfying way-Victor Hugo used to define melancholia as "the pleasure taken into being sad"23. Marcel, one evening, jumps out of the carriage to check the presence of the Beauty he once again located in a gorgeous passer-by; then to his utter astonishment the girl happens to be "the old Mme Verdurin", one of his old acquaintances.... Anyway some doubt still remains; what if he or she was the one "I would have loved [and] who knew it" ${ }^{24}$ ?

Would a photo be of any help? On the one hand, photography seems to make the Romantic wish to "suspend the flight of time" come true ${ }^{25}$; but on the other hand, this suspension would tend to disenchant these brief encounters, and Baudelaire decried photography because it was threatening the skills of the flâneur. Photography "came into its own as an extension of the eye of the middle-class flâneur", and "the photographer, an 'armed version of the solitary walker', could produce 'virtual' visual records of his flânerie"; but "the passion for roaming contradicted the 'fixing' of the visual image onto a photographic record" which was more filled with "history and memory" ${ }^{26}$ than with imagined Beauty. Besides, this fixing does not help to answer the question of the localization of Beauty either... However, things have changed since Proust and Baudelaire; technical improvements and new uses of cameras, complete 
with Internet 2.0, allow us to forever freeze innumerable passers-by all over the world, regardless of the speed at which the carriage is driving.

Incidentally, real passers-by are no longer required: nowadays, even when they walk downtown, postmodern flâneurs keep staring at the screens of their mobile phones, maybe because it is more comfortable to be shot by the arrow of Beauty through a "virtual visual record" than through the vividness of a walk among the crowd. But is it really the same thing? Proust wrote: "the impossibility of stopping and accosting a woman, the likelihood of not being able to find her again some other day, gives her the same sudden charm as is acquired by a place when illness or poverty prevents one from visiting it." ${ }^{27}$ But in a networking world, "love at last sight" is never certain, especially on a blog claiming half a million page views a day. The passer-by can even recognize herself on the picture and post her own comment. This is the case, for example, with the December 11 pale girl:

"Dear Sartorialist, thank you so much for including me, and thank you to all those who left such sweet comments, really heart warming. See you lovelies in the streets! With gratitude" (<PriceLes $>)$

\section{Blurring the triangle of enunciation}

Calling a photo a "virtual visual record" is somehow immanentist; it is like pretending the camera is a simple extension of the eye. Yet the camera is not. Not only is it a machine, but its use raises more ethical questions than the use of the eye, precisely because it records and stores the appearance of people.

Let's begin from the start. From the point of view of the photographer, there are only two possible ways to deal with the subject when you are going to take a picture of somebody walking on the street: asking for the authorization before or, if you are looking for spontaneity, after the shot; or not asking for it, at the risk of provoking a direct confrontation with the model, or being sued once the picture is published. Now from the point of view of the passer-by, there are three ways to to respond to the photographer's request (when formulated): refusing the authorization, giving it for free, or selling it. The third solution changes the status of model into that of a professional performer, complete with the risk of eschewing found grace and spontaneity back once one knows a camera is here.

As far as one knows after the reading of the paratext surrounding The Sartorialist website, "Schuman asks permission, and sets his shots up carefully once he's obtained it" $^{28}$. But of course some doubt remains here as well, even if it is a fictional doubt born from the stories we tell ourselves when thinking how the pictures have been taken. For example, what about the pictures shot from behind? Or the numerous pictures of somebody self-absorbed in their cellphone, seemingly oblivious of the presence of any observer, as if the photographer had been waiting for such a suspension of watchfulness to discreetly shoot? Right or wrong, whether permission has been granted or not, this kind of picture could put us into the position of the voyeur, the one who stares on the sly-note the French locution for "on the sly", à la dérobée, suggests that the situation is akin to a robbery, since dérober means to steal . But we are currently living in the 21st century, and privacy is not what it used to be. Privacy is out of fashion, in the literal and in the figurative senses. "Such blogs exist for Tel Aviv, Stockholm, Moscow, Sydney, Seoul, Berlin, Dublin, London-you name it. Survey them one morning 
over coffee, and you will feel like a boulevardier of the whole world, breezing past one stunning creature after another, free to cruelly assess or dumbly gaze-at supreme leisure and invulnerable to reciprocal scrutiny." ${ }^{29}$

And why do we benefit from such a comfortable invulnerability? Because on the computer screen, grace is mediated. It is so mediated that it even becomes hard to localize-we feel it but we do not exactly know which object causes it. If, as a consequence, a photographed person moves us, which one of the objects involved is the cause? Is it the pixels of which the picture is made, i.e., the plastic composition created by the photographer? Or is it rather the real counterpart of the pixels, i.e., the living person who served as a model? These questions remind us of Marcel sitting in his carriage: was Beauty in the passer-by or in his imagination? The fact that time is on our side-we can stare at the screen as long as we desire it-does not help us. Who's in charge when grace and beauty are enunciated by a fashion blog?

Three instances share responsibility for this enunciation:

(1) The Model. The creative choice of clothes are hers; the bodily hexis, the smile and the gesture are hers. But her amount of responsibility is not easy to assess: on the one hand, maybe she did not do it on purpose. She leads her daily life heedlessly; she did not intend to be graceful. On the other hand, maybe has she acted as her own metteur en scène, carefully picking up items in her wardrobe and consciously striking a graceful pose knowing the photographer was there. In both cases anyway, the Sartorialist offers "an instant-gratification blend of artistry and reality, starring appealing amateurs who are their own stylists." ${ }^{30}$

(2) The Observer. Without my imagination, my beliefs and my desires, there would not be any grace in this cold conglomerate of pixels. But once again, I cannot escape the Proustian dilemma: maybe the model is really graceful, and her or his beauty is objective and not subjective.

(3) The Artist. Not only is he the mediator between (1) and (2), but he sets the scene in order to make the common uncommon. Numerous commentators think The Sartorialist offers "glimpses of street style made glamorous by Schuman's lens" ${ }^{\prime 1}$. Besides, Mr. Schuman claims he arranges reality each time he takes a picture, seeing himself as the curator of a life-scale exhibition: "it's definitely a curated context. It's my altered reality." ${ }^{32}$ Some people say they would rather Schuman allow them to look at the real passers-by: "And maybe this is the weakness of his work (...): he portrays people in the most flattering possible light, literally and figuratively." ${ }^{33}$ But the majority of the users want to see him as an artist:

"What a beauty, I'm sure everything will look amazing on her!!!! You captured her elegance like nobody else can!" (<Elena $>)^{34}$.

But even "carefully set up" by Mr. Schuman, the photos use parts of the (imperfect) real world. And even if the model disguises himself or herself, like an actor in a comedy of his making, and if the observer limits herself to fantasies, losing touch with reality, it is impossible to escape from determinations, norms and connotations.

\section{Can anybody be graceful for one hundredth of a second?}

By the end of the 19th century, the Lumière brothers had already begun to send operators all over the (colonized) world in order to see how "others" were living. Suddenly, being in downtown Paris and thinking that thousands of kilometers away, at this very moment, some people were doing their usual activities, unaware of our own 
existence, was becoming far less vivid and fascinating than to watch them going about them. Virginia Woolf underlined it in her 1926 essay on cinema: "We behold [people on the screen] as they are when we are not there. We see life as it is when we have no part in it. As we gaze we seem to be removed from the prettiness of actual existence". Watching them, "we have time to open our minds wide to the beauty and register on top of it the queer sensation-this beauty will continue, and this beauty will flourish whether we behold it or not" 35 .

Nowadays, this function of monitoring is less provided by cinema and TV than by the internet. In addition to the countless online surveillance cameras fastened on roofs, public places, satellites and drones, millions of blogs and personal pages give out an overwhelming daily ration of snapshots taken from the course of things. It comes in such great quantities that one is reminded of Jorge Luis Borges's famous fantasy about a map so precise it is the exact same size as the territory it first intended to stand for ${ }^{36}$. This continuous duplication of the streets produces a feeling that J. Baudrillard once called hyperreality-when "entertainment, information, and communication technologies provide experiences more intense and involving than the scenes of banal everyday life" ${ }^{37}$.

But the case of fashion blogs like The Sartorialist go further than the experience of a feeling, since they require our real participation. The standard way to participate, as we have seen above, simply consists in adding a comment under a posted picture; a more active way consists in rushing to your wardrobe, picking up what you just learned to be fashionable items, and taking it to the streets to possibly embody one of these chic characters whose frozen silhouette will spellbind the internet users. Maybe you will be photographed by Mr. Schuman himself or by any other blogger able to "give viewers the sense that they are in the urban splendor too, or could be, or should be - strolling or sauntering, rather than linking and clicking." ${ }^{\prime 3}$ Indeed, it is true that The Sartorialist somehow makes us want to do it for real, i.e., to dress up in order to draw attention or to let the "real self" appear. It somewhat provides a cautious version of Andy Warhol's over-used 1968 prophecy: instead of "In the future, everyone will be world-famous for fifteen minutes", The Sartorialist claims that in the present, everyone can be graceful for one hundredth of a second-graceful hence famous, thanks to the blog.

Not all of the fashion blogs function in this manner, far from it. A lot of them do not give unknown people a chance to become "iconic", often because they are devoted to their own single founder, as if Aphrodite had permanently blessed him or her ${ }^{39}$. The Sartorialist spares us such narcissism. Unlike many of its imitators, such as The Wearist, which consists in pictures of her founder in different clothes ${ }^{40}$ or Garance Doré's famous fashion blog, which is overwhelmed by the personal advice and the commentaries of its owner ${ }^{41}$, Mr. Schuman takes no advantage of his position by systematically staging himself. Not to mention the risk of being mocked. There are so many merciless amateur photographs waiting for us to look ridiculous that one can feel grateful to Mr. Schuman for waiting, on the contrary, for our graceful moments.

How much time does he have to wait? Is anybody really likely to flaunt grace, lacing his shoes in the middle of the street or typing on her cellphone, even for one hundredth of a second? Sometimes it's a question of national belonging. Being born Italian and living in Milan, for example, seems to be an irreplaceable advantage when you are a man-if one believes what users wrote under "Monday, November 4, 2013: On the Street... Via Catena, Milan", showing an elegant signore on his bike: 
"Italy... What more is there to say... :-) I sometimes have the feeling that the Italians simply absorb this great style from the very moment they are born! Being stylish is simply inevitable for them I guess" (<Welniany Rynek $>$ )

"Only in Italy does gentleman have his bike toning with his suit!! Love it." (<Lynne Reid>)

"Gentlemen take note: this man knows the right way to dress! The Italians do indeed have an innate sense of style that the rest of us can learn from." (<Scott $>$ )

"I wish all *older men in England dressed like this... and not in baggy tracksuit bottoms!!" (<Jessica Rose>)

But more obvious determinism seems to be at work when one faces body norms and what Pierre Bourdieu called distinction, suggesting we are not all equal in the enchanted world of grace The Sartorialist asks us day after day to join in.

\section{Bodily hexis and distinction}

At first glance, there is something refreshing in the photos published by The Sartorialist. The "profane" bodies easily win the confrontation with the "sacred" ones, whose owners are paid to show how well their clothes fit them. Compared to amateurs, professional models look skinny, weird, unnatural in their gestures and expressions, and the accumulation of their perpetually brand new clothes have overtones of meaningless artificiality. After all, to extend to clothes what Ferdinand de Saussure said of words, meaning is created through opposition, and there is often more opposition in a common wardrobe than into a fashion show: old clothes are opposed to new ones, and expensive clothes to cheap ones. The variety of styles is greater, too, since nobody wears clothes made by a single designer anymore. The "total look" is out of fashion, being nowadays replaced by eclecticism: wearing a Yohji Yamamoto jacket upon your old pair of jeans will make you look cool, while wearing it upon another Yohji Yamamoto item (or any other expensive-chic item of your wardrobe) will make you look like a pathetic victim of merchandization, mistaking style for buying power. That is also why "I can do it too!" is the current refreshing reaction of the newcomers to The Sartorialist, who are promt to think: "It wouldn't take much for me to become as graceful as she or he is".

Maybe buying the same jacket would suffice to project all around myself, wherever I go, the same intimidating aura as that of the previously mentioned Manhattan Gavroche girl with her bomber:

"I want that jacket, where can I get it?" (<Anna-bird>).

"The proportions are perfect and I'm going to hunt for a jacket like that now"

$(<\mathrm{Te}>)$.

But do <Anna-bird $>$ and $<\mathrm{Te}>$ really believe that buying the same jacket is enough? The gavroche girl has it. And "it" is neither the jacket nor any piece of buyable merchandise. As professional dancers used to say, the girl on the picture "is up". It means her antigravity muscles push her entire body upwards, giving her the silhouette of a Golden Age movie star-a feeling that did not escape the attention of the blog users:

"Makes me think of Kate Hepburn about to fly off with Howard Hughes"

(<Monsieur Marcel>).

Thus, to have it means, first of all, to show a particular bodily hexis, to coin a term often used by Pierre Bourdieu, and bodily hexis is more or less impossible to acquire once you are a grown-up, even if you would be exhausting yourself in dance and yoga 
courses. "Bodily hexis is political mythology realized, em-bodied, turned into a permanent disposition, a durable way of standing, speaking, walking, and thereby of feeling and thinking" ${ }^{\prime 2}$. It is not even a question of displaying grace or not; it is a question of displaying it owing to one's "nature". The performance of grace must be unthought, if not unconscious. In order to be picked up by Mr. Schuman, you have to be "effortlessly stylish; you don't try, you just are... [Because] he's a hunter of free-range sprezzatura" ${ }^{43}$.

Then comes shape. If The Sartorialist seems to welcome all skin colors and ethnicities (and almost all ages), fat, sick and disabled bodies remain offscreen. Since obesity, disease and disability are modern scarecrows, such an absence can easily be explained by the current use of fashion blogs. These blogs intend to elicit pleasant daydreams, not nightmares. Everybody knows there are feelgood movies, whose bill of specifications preclude making the audience feel awkward; thus, there are feelgood blogs too. The economic pressure is even weaker for a fashion blog than for a fashion magazine: glamorous ads for ruinous items are far more frequent in the former than in the latter ${ }^{44}$. But being bucked up does not prevent norms from being embodied. On the contrary, so-called normality and desirability are constructed through "a process of iterability, a regularized and constrained repetition of norms", to quote Judith Butler. And "this iterability implies that 'performance' is not a singular 'act' or event, but a ritualized production, a ritual reiterated under and through constraint, under and through the force of prohibition and taboo, with the threat of ostracism and even death." ${ }^{45}$

This is particularly true with The Sartorialist, where no queer space is available. Girls look like (and therefore are, it is tempting so say) girls, and boys look like boys. The few moments of queerness do not seem to be much appreciated by the current users. For instance, an unusual picture of somebody whose biological sex is not obvious, "Wednesday, November 6, 2013. On The Street... The Strand, London", causes normative remarks ${ }^{46}$. It shows a young man with blond hair in a bun, wearing a kilt sitting on a coffee terrace:

"At first I thought he was woman! Great style anyway!" (<Laura>)

"Oh my! What hairy legs she has!" (<Erica>)

"chloe sevigny... shave your leg LOL" ${ }^{47}(<\mathrm{CBC}>)$

But knowing that on the web there always are vigils, somebody tried to denounce this normativity:

"Sometimes I am surprised to see someone tagged in one of the Men or Women categories, and am reminded that making comments that poke fun at someone's crossing of gender categories is a very dangerous thing to do." (<Manon>)

A single comment on norms does not suffice to "deconstruct" norms, all the more so as gender norms are not the only norms fashion blogs convey. There are, first and foremost, economic norms: apparently, the message is "you can be graceful with inexpensive clothes if they are carefully chosen and mixed", but everybody knows, as I mentioned earlier with the Yohji Yamamoto jacket (whose average cost is one month of minimum wage), that inexpensive clothes are at their best a setting for some luxurious items. That is why The Sartorialist is seen, by some of its parodists, as a partner of inegalitarian capitalism and ruling classes ${ }^{48}$. There are also beauty norms, of course: fashion blogs display just as many beautiful faces as nice clothes; they contribute to construct what I have elsewhere called aphrodism ${ }^{49}$, i.e., the irrational tendency to give 
preference to beautiful and handsome persons, whether it be for a position at work or a simple conversation.

To finish, one must not forget the pressure put on the perpetual invitation to be wearing something original and noteworthy-because wearing it is the indisputable sign you are, as an individual, original and noteworthy. "Don't by shy, do it, show your real inner self". Yet it is an illusion to believe that "Schuman photographs people on the street, where they are completely divorced from any social or economic context. They seem to have no background or job." ${ }^{50}$ On the contrary, everything serves as social signals, especially the clothes and the way you wear them. Surfing The Sartorialist you will see everyday fashion if and only if "you consider tall heels, wild prints, and bold colors 'everyday." ${ }^{51}$ Astonishing outfits, daring combinations and infrequent colors go better with some ways of life, some jobs and a particular "cultural capital" 52 . If your life, your job and your cultural capital do not fit with what you wear, they will be categorized as "unnatural" and you will be seen as a "fashion victim".

Repetition of these norms ultimately causes a feeling of exclusion. The user sees himself or herself as a spectator unable to become an actor of street fashion:

"Beautiful \& elegant. I would love to be able to dress like that. It looks perfect on her" $(<\operatorname{Kim}>)^{53}$.

It is still a feelgood blog, but it only feels good to look at grace. Thinking "I could do it too" is no longer conceivable.

\section{Conclusion: Don't Try}

"Web surfing" is an antithetic phrase. The so-called horizontal surface of the sea of websites is, rather, a vertical forest of sign-posts and guidelines. It is less a matter of surfing or skating than a matter of weaving in and out of norms, models, requests and temptations. One of the ways to win this slalom race, or at least to finish it without too many wounds, is to maintain an aesthete's gaze whatever happens. It is how Marcel and Swann, the heroes of In Search of Lost Time, look at the women they fall in love with. "These glimpsed encounters made for greater beauty in a world which sows such flowers, rare though common, along every country roadside, a new spice being added to life by the untried treasures of each day, by every outing with its unkept promises." ${ }_{54}$

At the end of his life, Swann understands the beauty he was seeing on the face of Odette was in his own eyes-he thought she was a Botticelli, and only a connoisseur of the history of painting like him could have this kind of belief. In the same way, Marcel learns to stop suffering from the "unkept promises" of the beautiful passers-by he glimpses. The lesson of In Search of Lost Time therefore is that the beauty of the interpretive gesture itself goes beyond the beauty of the work of art (whether it is a fine painting or a nice body). Perceiving the treasure, knowing how to appreciate it, already is a great reward, and it is better to leave this treasure "untried". Odette, in The Past Recaptured, tells Marcel how she renounced the great love of her youth: that love was so pure and intense it reached an acme from which it would ineluctably begin to crumble; breaking up was, then, the only solution to treasure it as an everlasting souvenir. But Marcel decides to go one step further, believing it is safer not to try to jump out of the carriage. Even if he or she is "the one", it will never be as durably pleasurable as the idea that she or he could have been the one. 
In such a perspective, dear <Anna-bird $>$ and $<\mathrm{Te}$, you can play, as long as you wish, with the idea of buying an adorable little brown bomber like the one you just saw on The Sartorialist website. But my advice would be to not do it for real, for sooner or later you are bound to be bitterly disappointed. As Proust writes, "the mere act of entertaining the possibility of artificially fostering it is an implicit acknowledgement that it is an illusion." ${ }^{55}$ By one of the strange coincidences literature is accustomed to, this Proustian advice appears as the epitaph American poet Charles Bukowski wanted to be engraved on his grave: "Don't try"... ${ }^{56}$

\section{BIBLIOGRAPHY}

Amed, Imran. "The Business of Blogging: The Sartorialist", The Business of Fashion (3 Oct., 2011).

Avins, Mimi. “The Picture Of Style”. Los Angeles Times (01 Nov. 2009).

Benjamin, Walter. The Writer of Modern Life: Essays on Charles Baudelaire. H. Eiland trans.

Cambridge: Harvard University Press, 2006.

Bordwell, David. Foreword to: Noël Carroll. Theorizing The Moving Image. Cambridge: Cambridge U. Press, 1996.

Borges, Jorge Luis. A Universal History of Infamy. N. T. de Giovanni trans. London: Penguin Books, 1975.

Bourdieu, Pierre. Distinction. A Social Critique of the Judgement of Taste. R. Nice trans. Cambridge: Harvard University Press, 1987.

Bourdieu, Pierre. Outline of a Theory of Practice. R. Nice trans. Cambridge: Cambridge University Press, 1977.

Brereton, Geoffrey (ed.) The Penguin Book of French Verse: Nineteenth century. London: Penguin Books, 1961.

Butler, Judith. Bodies That Matter: On the Discursive Limits of "Sex". New York: Routledge, 1993.

Carroll, Noël. "Prospect for film theory: a personal assessment”. Post-Theory: Reconstructing Film Studies, D. Bordwell \& N. Carroll (eds). Madison: U. of Wisconsin Press, 1996.

Collins, Lucy. "On the Street”. Cardus, May 13, 2011.

Friedberg, Anne. Window Shopping: Cinema and the Postmodern. Berkeley: U. of California Press, 1993.

Heffernan, Virginia. "Pop Couture”. The New York Times (19 Dec. 2008).

Hugo, Victor. Les Travailleurs de la mer, III. Paris: Librairie Internationale, 1866.

Jullier, Laurent. Hollywood et la difficulté d'aimer. Paris: Stock, 2004.

Kellner, Douglas. "Jean Baudrillard”. Stanford Encyclopedia of Philosophy on line (First published Fri Apr 22, 2005; substantive revision Wed Mar 7, 2007).

Killingsworth, Silvia. “And the Word of the Year Is...”. The New Yorker (19 Nov. 2013). 
La Force, Thessaly. "Sartorialust", The New Yorker (15 Sept. 2009).

Lengyell, Meghan. “Images On The Street: Fashion, Personal Style, And The Sartorialist”, dissertation for Ryerson University, Toronto, 2011.

Pappademas, Alex. "Up from the Streets". GQ (June 2012).

Proust, Marcel. In the Shadow of Young Girls in Flower. James Grieve trans. New York: Viking, 2002.

Reese, William (ed.) The Penguin Book of French Poetry 1820-1950. London: Penguin 1990.

Wagner, Geoffrey (ed). Selected Poems of Charles Baudelaire, New York: Grove Press, 1974.

Woolf, Virginia. “The Cinema”, The Arts (June 1926).

\section{NOTES}

1. <http://www.thesartorialist.com> Web. $13^{\text {th }}$ April.

2. < http://content.time.com/time/specials/packages/completelist/0,29569,1999770,00.html> Web. $13^{\text {th }}$ April.

3. $\quad$ http://content.time.com/time/specials/2007/style_design/article/ 0,28804,1609195_1609023,00.html.> Web. $13^{\text {th }}$ April.

4. Mimi Avins, "The Picture Of Style", Los Angeles Times, Nov. 01, 2009. <http:// articles.latimes.com/2009/nov/01/image/ig-sartorialist01> Web. $13^{\text {th }}$ April.

5. Imran Amed, "The Business of Blogging: The Sartorialist", The Business of Fashion, 3 Oct., 2011. <http://www.businessoffashion.com/2011/10/the-business-of-blogging-the-sartorialist.html> Web. $13^{\text {th }}$ April.

6. See for instance: <http://www.fakesartorialist.com> whose motto was "fashion takes itself too seriously". Or: <http://thecatorialist.blogspot.fr> which only shows elegant cats... Web. $13^{\text {th }}$ April (both).

7. See Meghan Lengyell, "Images On The Street: Fashion, Personal Style, And The Sartorialist", Ryerson University, Toronto, 2011. <http://digitalcommons.ryerson.ca/cgi/viewcontent.cgi? article $=2576 \&$ context=dissertations $>$ Web. $13^{\text {th }}$ April. According to David Bordwell, "SLAB" is an acronym for "Saussure-Lacan-Althusser-Barthes": see Foreword to Noël Carroll, Theorizing The Moving Image (Cambridge: Cambridge U. Press, 1996). Noël Carroll later added to the list Foucault, Deleuze, and Derrida, bringing the label close to "French Theory": see "Prospect for film theory: a personal assessment", in Post-Theory: Reconstructing Film Studies, D. Bordwell \& N. Carroll eds (Madison: U. of Wisconsin Press, 1996), 2.

8. Virginia Heffernan, "Pop Couture", The New York Times, Dec. 19, 2008. <http:// www.nytimes.com/2008/12/21/magazine/21wwln-medium-t.html?_r=0>

9. Amed, "The Business of Blogging".

10. < http://www.thesartorialist.com/photos/on-the-scene-aesop-bleecker-st-new-york/comments $>$ Web. $13^{\text {th }}$ April.

11. < http://www.thesartorialist.com/photos/on-the-street-fourteenth-st-new-york/ comments $>$ Web. $13^{\text {th }}$ April.

12. This comment is about the Italian bicycle rider, see below.

13. "Tuesday, November 5, 2013. On The Street... Piazza Oberdan, Milan" < http:// www.thesartorialist.com/photos/on-the-street-piazza-oberdan-milan-16/ - comments> Web. $13^{\text {th }}$ April.

14. < http://www.thesartorialist.com/photos/on-the-street-lafayette-st-nyc-4/ - comments> Web. $13^{\text {th }}$ April. 
15. Freaky Friday is a well-known 1972 novel (then a movie) in which a teenage girl awakens one Friday morning to find herself in the body of her mother. Note <shani> added a link to her own blog, whose tagline is: "She dreams in perfect French... but then she wakes up" (<http:// shedreamsinperfectfrench.com>. Web. $13^{\text {th }}$ April).

16. Marcel Proust, In the Shadow of Young Girls in Flower, ed. Christopher Prendergast, trans. James Grieve (New York: Viking, 2002), 292.

17. Proust, ibid.

18. Proust, ibid.

19. Selected Poems of Charles Baudelaire, Geoffrey Wagner ed. (New York: Grove Press, 1974).

20. Baudelaire quoted by Anne Friedberg, Window Shopping: Cinema and the Postmodern (Berkeley: U. of California Press, 1993), 29-30.

21. Walter Benjamin, The Writer of Modern Life: Essays on Charles Baudelaire, Michael W. Jennings ed. (Cambridge, MA : Harvard University Press, 2006), 185.

22. Proust, ibid.

23. Victor Hugo, Les Travailleurs de la mer, III (Paris: Librairie Internationale, 1866), 153, our trans.

24. Baudelaire, To a Woman... op. cit. Same idea in Nerval's An Alley in the Luxembourg Gardens: "She is, perhaps, the only one in the world whose heart would answer mine", The Penguin Book of French Verse: Nineteenth century, Geoffrey Brereton ed. (London: Penguin Books, 1961), 96.

25. "O time, suspend your flight!", wrote Alphonse de Lamartine in The Lake, in which he misses the fugitive moments of happiness: "What! gone for ever? What! entirely lost? Will time gave them, time that effaces them, never give them back to us": Lamartine, "The Lake", The Penguin Book of French Poetry 1820-1950, William Reese ed. (London: Penguin 1990), 9.

26. Friedberg, Window Shopping, 30.

27. Proust, ibid.

28. Alex Pappademas, “Up from the Streets”, GQ, June 2012, p. 98.

29. Heffernan, "Pop Couture".

30. Avins, "The Picture of Style".

31. Thessaly La Force, "Sartorialust", The New Yorker, Sept. 15, 2009. <http:// www.newyorker.com/online/blogs/books/2009/09/sartorialust.html> Web. $13^{\text {th }}$ April.

32. Pappademas, "Up from the Streets".

33. Pappademas, "Up from the Streets".

34. Comment under the Gavroche girl, op. cit.

35. Virginia Woolf, "The Cinema", The Arts, June 1926. Online: <http://www.woolfonline.com>. Web. $13^{\text {th }}$ April.

36. Jorge Luis Borges, Del rigor en la ciencia (On Exactitude in Science), 1946. Trans. N. T. de Giovanni, A Universal History of Infamy (London: Penguin Books, 1975). The idea was in Lewis Carroll's 1889 Sylvie and Bruno Concluded.

37. Douglas Kellner, "Jean Baudrillard", Stanford Encyclopedia of Philosophy, 2007. Online: <http:// plato.stanford.edu/entries/baudrillard> Web. $13^{\text {th }}$ April. In spite of the fact Neo, its main character, keenly reads Baudrillard's Simulacra and Simulation, the Matrix trilogy is not an exemplification of this concept, since the majority of human beings of the fictional world it depicts doesn't differentiate reality from its representational counterpart.

38. Heffernan, writing about Garance Doré's blog, "Pop Couture".

39. These "blogs about me" are more complex versions of the now very popular "selfie", i. e. a "photograph that one has taken of oneself, typically one taken with a smartphone or webcam and uploaded to a social media website." (The New Yorker, November 19, 2013. <http:// www.newyorker.com/online/blogs/culture/2013/11/selfie-word-of-the-year.html> Web. $13^{\text {th }}$ April.).

40. <http://thewearist.blogspot.fr> Web. $13^{\text {th }}$ April.This website gives as a definition of a "wearist" : "One that believes that the act of wearing is the very thing keeping life stylish." 
(Either this definition is tautological either it refers to the Nineteeth-Century dandy spirit, depending on the meaning one gives to "stylish" when associated to "life").

41. < http://www.atelierdore.com/fr/> Web. $13^{\text {th }}$ April.

42. Pierre Bourdieu, Outline of a Theory of Practice (Cambridge: Cambridge University Press, 1977), 93-4.

43. Pappademas, "Up from the Streets".

44. "Magazines are driven by fear, said Mr. Schuman. They have to keep these advertisers" (The Talks, September 28, 2011. <http://the-talks.com/interviews/scott-schuman-the-sartorialist> Web. $13^{\text {th }}$ April.).

45. Judith Butler, Bodies That Matter: On the Discursive Limits of "Sex" (New York: Routledge, 1993), 95.

46. < http://www.thesartorialist.com/photos/on-the-street-the-strand-london-7/ - comments Web. $13^{\text {th }}$ April.

47. The model shows a (very weak) resemblance with American film actress Chloë Sevigny.

48. "The work of the founder [of "The Fake Sartorialist" blog] may be seen as a fight for freedom: the "fake" in the Fake Sartorialist stands for "the little guy" against the cultural and social giants that the Sartorialist aligns himself with and represents": Minh-Ha Pham, "What is this 'Fake' in the Fake Sartorialist?". <http://threadbared.blogspot.fr/2010/04/what-is-this-fake-in-fakesartorialist.html> Web. $13^{\text {th }}$ April.

49. L. Jullier. Hollywood et la difficulté d'aimer. Paris: Stock, 2004, p. 139.

50. Collins, Lucy. "On the Street", Cardus, May 13, 2011. <http://www.cardus.ca/comment/ article/2780/on-the-street> Web. $13^{\text {th }}$ April.

51. Olivia Hodge, 18 year old journalism student at The University of Alabama, on her blog (<http://oliviainalabama.wordpress.com/category/the-sartorialist $>$ Web. $13^{\text {th }}$ April.).

52. Pierre Bourdieu. Distinction. A Social Critique of the Judgement of Taste. R. Nice trans. Cambridge: Harvard University Press, 1987, p. 13.

53. Comment under the Gavroche girl, op. cit.

54. Proust, ibid. My italics.

55. Proust, ibid.

56.

\section{INDEX}

Subjects: Photography

Keywords: visual studies, photography, reception studies, fashion, blog, The Sartorialist

\section{AUTHORS}

\section{LAURENT JULLIER}

Professeur d'études cinématographiques à l'Institut Européen de Cinéma et d'Audiovisuel de l'Université de Lorraine et directeur de recherches à l'Institut de Recherches sur le Cinéma et l'Audiovisuel de l'Université Sorbonne Nouvelle-Paris III.

laurent.jullier@sorbonne-nouvelle.fr 